\title{
Lung dust and lung iron contents of coal workers in different coalfields in Great Britain
}

\author{
I. BERGMAN and C. CASSWELL \\ Safety in Mines Research Establishment, Department of Trade and Industry, Sheffield S3 7HO
}

\begin{abstract}
Bergman, I., and Casswell, C. (1972). Brit. J. industr. Med., 29, 160-168. Lung dust and lung iron contents of coal workers in different coalfields in Great Britain. Lung dust analyses from seven coalfields are studied and it is found that the average dust composition varies significantly with the rank of coal. The higher the rank, the higher the coal percentage and the lower the quartz percentage of the lung dust. This holds for all coalfields except in Scotland, where the lung dust contains mainly soot instead of coal.

Samples of airborne dust collected at the coalface in different coalfields show a similar but small variability of composition with rank of coal, and the results from Scotland are in good agreement with the results from other coalfields.

The amount of iron in simple pneumoconiosis lungs is related to their mineral and coal contents and to the factor 'years underground'. The strongest relationship is with coal and mineral for coalface workers from England. For pit accident cases (all simple pneumoconiosis) mineral is important as well as years underground, while for simple pneumoconiosis cases from Scotland, years underground is the most important factor.
\end{abstract}

A number of previous studies have dealt with the dust isolated from the lungs of coal workers suffering from pneumoconiosis. The relationships between the amount and composition of lung dust and the industrial history, grade of pathology, and $x$-ray category have been examined (King and Gilchrist, 1945; King, Maguire, and Nagelschmidt, 1956; Rivers, Wise, King, and Nagelschmidt, 1960). In two studies (Spink and Nagelschmidt, 1963; Faulds, King, and Nagelschmidt, 1959) differences were observed between the composition of lung dust from South Wales and that from Cumberland and the Wigan area of Lancashire.

A few years ago, the basis of this work was extended to cover all major coalfields in Great Britain. Between 1952 and 1964, a series of lungs of miners coming to necropsy was collected with the object of examining the relationships between radiological appearance, the industrial histories of the miners, and the dust contents of their lungs. A preliminary report was issued by Rossiter et al.
(1967) and a further report by Casswell, Bergman, and Rossiter (1971). In a proportion of the cases, however, information about the pathology of the lungs or the quality of the radiographs taken before death was not considered to be good enough for quantitative pathological or radiological data to be included in a study of their correlation with the dust analyses. All the results for lung dust composition for the full series have, however, been reviewed in the present paper without special regard to pathology or $x$-ray category except to differentiate between simple pneumoconiosis (SP) and the complication of progressive massive fibrosis (PMF). Major changes in the method of quartz analysis were made some years ago (Gordon and Harris, 1956), and for this reason the data given by King and Gilchrist (1945) and King et al. (1956) are not considered here.

Lung dusts of coal miners consist mainly of coal and the minerals quartz, mica, and kaolin. Quartz is a specific hazard which causes silicosis when its proportion in the airborne dust or lung dust is large 
(Nagelschmidt, 1960); coal is the main constituent of most coal-mine dusts, but it contributes, weight for weight, less to the $x$-ray category of SP than quartz or the other clay minerals (Rivers et al., 1960; Rossiter et al., 1967; Casswell et al., 1971). For these reasons the dust composition has been characterized by listing the coal percentage $\left(C_{D}\right)$ and the quartz percentage $\left(Q_{D}\right)$ of each lung dust.

Coal is usually classified according to the values of two parameters. These parameters are the 'volatiles' content of the coal and the caking properties of the coal, as defined by the Gray-King coke type (National Coal Board, 1960). The purpose of the classification is to describe the rank or degree of coalification of the coal substance. As the rank of the coal increases from lignite through bituminous coal to anthracite, so the volatiles content of the coal decreases, the oxygen and hydrogen contents decrease, and the amount of fixed carbon increases. In this paper we have chosen the carbon content of the coal substance (expressed as a percentage of the dry mineral-matter-free coal) as a measure of rank and have termed it 'coal rank factor R'. For lowrank bituminous coals $\mathrm{R}$ is about $80 \%$, while for high-rank anthracites it is about $95 \%$. Table 1 lists the coalfields of Great Britain in descending order of the rank of coal mined. It will be seen that the average value of $R$ also decreases monotonically.

Iron-containing materials are found in pneumoconiotic lungs in larger quantities than in normal lungs. This increase in iron content, which is related to the coal and mineral content of the lungs (Rossiter et al., 1967; Casswell et al., 1971), is too large to be accounted for by blood in the vessels of the lung; it is almost certainly due to endogenous iron deposits such as haemosiderin (Bergman, 1970). Iron analyses were carried out on the present series of lungs, and the relationship between iron content and parameters derived from the dust content and industrial histories was examined.

\section{Material and methods}

Whole lungs fixed in formol saline were cut into small pieces, minced, and dried to constant weight at $105^{\circ} \mathrm{C}$ in a vacuum oven (usually for two days). The dried lung was ground (in an 'end-runner' mill) until more than $99 \%$ passed through a British Standard 100-mesh sieve (mesh size $152 \mu \mathrm{m}$ ). The lung powder was equilibrated with atmospheric moisture, to give a product of relatively stable moisture content, and stored in a sealed bottle. When a sample was taken for analysis, a second sample was taken for moisture determination. The latter was heated at $105^{\circ} \mathrm{C}$ at atmospheric pressure overnight (18 hours), cooled for 20 minutes in a desiccator, and the weight loss was measured.

For the lungs analysed, the name or names of the pits at which the men had worked, and the type of work which they had been doing, were recorded. From the pit names an average value for the carbon content of the seam coal (R) was obtained from information kindly supplied by the National Coal Board's Coal Survey. The working histories were also used to distinguish men who had only or mainly worked on the coalface from other underground workers, who included hauliers, repairers, rock workers, and men with mixed exposure histories. For the purposes of this study, coalface workers are defined as miners who had worked for at least two-thirds of their total underground life at the coalface.

The coal content $\left(C_{L}\right)$ of the lungs was calculated from the weight loss at $380^{\circ} \mathrm{C}$ of the residue of a digestion of the lung tissue. The two methods of digestion, either with alkali (King and Gilchrist, 1945) or with glacial acetic acid and ammonium acetate followed by a digestion with formic acid (Bergman, 1966), gave results in close agreement.

The mineral matter content $\left(M_{L}\right)$ was determined by ashing the acetic-acid digestion residue at $380^{\circ} \mathrm{C}$, or by ashing a sample of lung at $380^{\circ} \mathrm{C}$ and then washing this ash with $2 \mathrm{~N} \mathrm{HCl}$ to remove the endogenous lung salts (King et al., 1956).

The quartz content $\left(\mathrm{Q}_{\mathrm{L}}\right)$ was determined on a sample of the acid-washed ash using an $x$-ray diffractometry technique (Gordon and Harris, 1956).

The total-iron content of the present series of lungs was determined by $x$-ray fluorescence analysis of the dried and ground lung material, using an adaption of the method of Cullen (1962). This method of determining iron in lung material was shown to be accurate to within about $\pm 5 \%$ by comparison with the spectrophotometric method of Wootton (1958).

\section{Results and discussion}

\section{Lung dust contents and industrial histories}

Of the 322 coal workers in the extension of the series considered by Rossiter et al. (1967) and Casswell et al. (1971), the 314 for whom complete dust analyses and adequate industrial histories were available have been included in this study. In Table 1 the data have been grouped according to National Coal Board Division in the order of decreasing average rank of the coal mined. The lungs from South Wales miners were subdivided into two groups, of higher and of lower rank, corresponding approximately to anthracite and steam coal. The boundary was taken at a coal rank factor $R$ of $92 \%$ for the pits where the men had worked. Each of the above groups has been further subdivided according to whether the lungs showed SP or PMF, and whether the cause of death was sudden owing to a pit accident or occurred from other causes. No pit accident cases with PMF were encountered.

For each group and subgroup Table 1 gives the number of cases, the age at death, the total dust in the one lung analysed, and the dust accumulation rate (A) for two lungs. This latter rate was calculated by dividing twice the total dust figure by the number of years worked underground.

The cases of PMF stand out, in that the accumulation rate for almost all the groups is clearly higher 
TABLE 1

Age at Death, Number of Cases, Rank, Total Dust and Dust Accumulation Rate of 314 Cases Divided ACCORDING to NCB Division AND subdivided ACCORDING to Type of PNeumoconiosis and

CAUSE OF DEATH

\begin{tabular}{|c|c|c|c|c|c|c|c|c|c|c|c|}
\hline \multirow{2}{*}{\multicolumn{4}{|c|}{ Coalfield }} & \multirow{2}{*}{ Class $^{1}$} & \multirow{2}{*}{$\begin{array}{l}\text { No. of } \\
\text { cases }\end{array}$} & \multirow{2}{*}{$\begin{array}{c}\text { Age at } \\
\text { death } \\
(y r)\end{array}$} & \multirow{2}{*}{$\begin{array}{l}\text { Total dust } \\
\text { one lung } \\
(g)\end{array}$} & \multirow{2}{*}{$\begin{array}{c}\text { Accum. } \\
\text { rate two } \\
\text { lungs } A \\
(g / y r)\end{array}$} & \multicolumn{3}{|c|}{$\begin{array}{c}\text { Average rank factor } R^{2} \\
(\% \text { carbon })\end{array}$} \\
\hline & & & & & & & & & $S o+S^{*}$ & $P$ & All cases \\
\hline \multicolumn{4}{|c|}{ S. Western (high rank) } & $\begin{array}{l}\text { So } \\
\text { S* } \\
\text { P } \\
\text { All }\end{array}$ & $\begin{array}{r}29 \\
23 \\
6 \\
58\end{array}$ & $\begin{array}{l}58 \cdot 0 \\
45 \cdot 3 \\
58 \cdot 7 \\
53 \cdot 0\end{array}$ & $\begin{array}{r}10 \cdot 95 \\
9 \cdot 86 \\
33 \cdot 13 \\
12 \cdot 81\end{array}$ & $\begin{array}{l}0 \cdot 72 \\
0 \cdot 87 \\
2 \cdot 31 \\
0.94\end{array}$ & \} $92 \cdot 4$ & $92 \cdot 0$ & $92 \cdot 4$ \\
\hline \multicolumn{4}{|c|}{ S. Western (low rank).. } & $\begin{array}{l}\text { So } \\
\mathbf{S}^{*} \\
\mathrm{P} \\
\text { All }\end{array}$ & $\begin{array}{l}28 \\
11 \\
13 \\
52\end{array}$ & $\begin{array}{l}60 \cdot 9 \\
50 \cdot 9 \\
66 \cdot 7 \\
60 \cdot 2\end{array}$ & $\begin{array}{r}11 \cdot 21 \\
8 \cdot 83 \\
12 \cdot 84 \\
11 \cdot 11\end{array}$ & $\begin{array}{l}0 \cdot 64 \\
0 \cdot 53 \\
0 \cdot 73 \\
0 \cdot 64\end{array}$ & $90 \cdot 3$ & $89 \cdot 6$ & $90 \cdot 1$ \\
\hline \multicolumn{4}{|c|}{ Northumberland \& Durham .. } & $\begin{array}{l}\text { So } \\
\text { S* }^{*} \\
\text { P } \\
\text { All }\end{array}$ & $\begin{array}{r}15 \\
2 \\
19 \\
36\end{array}$ & $\begin{array}{l}60 \cdot 9 \\
58 \cdot 0 \\
59 \cdot 4 \\
60 \cdot 1\end{array}$ & $\begin{array}{r}11 \cdot 41 \\
8 \cdot 75 \\
15 \cdot 31 \\
13 \cdot 26\end{array}$ & $\begin{array}{l}0 \cdot 58 \\
0 \cdot 40 \\
0 \cdot 88 \\
0 \cdot 75\end{array}$ & \} $87 \cdot 8$ & $88 \cdot 4$ & $88 \cdot 1$ \\
\hline Yorkshire & . & . & . & $\begin{array}{l}\text { So } \\
\text { S* } \\
\text { P } \\
\text { All }\end{array}$ & $\begin{array}{r}15 \\
10 \\
9 \\
34\end{array}$ & $\begin{array}{l}61 \cdot 0 \\
45 \cdot 3 \\
61 \cdot 2 \\
56 \cdot 4\end{array}$ & $\begin{array}{r}10 \cdot 37 \\
4 \cdot 51 \\
15 \cdot 29 \\
9 \cdot 95\end{array}$ & $\begin{array}{l}0.52 \\
0.35 \\
0.90 \\
0.57\end{array}$ & 86.0 & $86 \cdot 0$ & $86 \cdot 0$ \\
\hline N. Western & . & . & . & $\begin{array}{l}\text { So } \\
\text { S* }^{*} \\
\text { P } \\
\text { All }\end{array}$ & $\begin{array}{r}13 \\
8 \\
6 \\
27\end{array}$ & $\begin{array}{l}67 \cdot 8 \\
38 \cdot 9 \\
69 \cdot 1 \\
59 \cdot 5\end{array}$ & $\begin{array}{r}11 \cdot 20 \\
3 \cdot 40 \\
8 \cdot 62 \\
8 \cdot 32\end{array}$ & $\begin{array}{l}0 \cdot 61 \\
0 \cdot 37 \\
0 \cdot 39 \\
0 \cdot 49\end{array}$ & $85 \cdot 1$ & $85 \cdot 4$ & $85 \cdot 2$ \\
\hline Scotland & . & .. & . & $\begin{array}{l}\text { So } \\
\mathrm{S}^{*} \\
\text { P } \\
\text { All }\end{array}$ & $\begin{array}{r}41 \\
0 \\
13 \\
54\end{array}$ & $\begin{array}{l}67 \cdot 2 \\
\overline{70 \cdot 5} \\
68 \cdot 0\end{array}$ & $\begin{array}{r}8.73 \\
\overline{11 \cdot 06} \\
9 \cdot 29\end{array}$ & $\begin{array}{l}0.42 \\
- \\
0.58 \\
0.46\end{array}$ & $83 \cdot 7$ & $84 \cdot 8$ & $84 \cdot 0$ \\
\hline W. Midlands & . & . & . & $\begin{array}{l}\text { So } \\
\text { S* } \\
\text { P } \\
\text { All }\end{array}$ & $\begin{array}{r}19 \\
3 \\
7 \\
29\end{array}$ & $\begin{array}{l}63 \cdot 5 \\
33 \cdot 7 \\
67 \cdot 6 \\
61 \cdot 4\end{array}$ & $\begin{array}{r}7 \cdot 33 \\
1.02 \\
16 \cdot 57 \\
8.91\end{array}$ & $\begin{array}{l}0.42 \\
0 \cdot 14 \\
1.03 \\
0.54\end{array}$ & $83 \cdot 6$ & $84 \cdot 3$ & $83 \cdot 8$ \\
\hline E. Midlands & . & . & . & $\begin{array}{l}\text { So } \\
\text { S* } \\
\text { P } \\
\text { All }\end{array}$ & $\begin{array}{r}17 \\
2 \\
5 \\
24\end{array}$ & $\begin{array}{l}62 \cdot 3 \\
61 \cdot 0 \\
66 \cdot 4 \\
63 \cdot 0\end{array}$ & $\begin{array}{r}6 \cdot 18 \\
9 \cdot 53 \\
14 \cdot 28 \\
8 \cdot 15\end{array}$ & $\begin{array}{l}0 \cdot 30 \\
0 \cdot 65 \\
0 \cdot 75 \\
0 \cdot 42\end{array}$ & $83 \cdot 2$ & $82 \cdot 5$ & $83 \cdot 1$ \\
\hline All divisions & . & . & . & $\begin{array}{l}\text { So } \\
\mathbf{S}^{*} \\
\mathbf{P} \\
\text { All }\end{array}$ & $\begin{array}{r}177 \\
59 \\
78 \\
314\end{array}$ & $\begin{array}{l}62 \cdot 8 \\
45 \cdot 8 \\
64 \cdot 6 \\
60 \cdot 1\end{array}$ & $\begin{array}{r}9 \cdot 64 \\
7 \cdot 39 \\
15 \cdot 09 \\
10 \cdot 56\end{array}$ & $\begin{array}{l}0 \cdot 53 \\
0 \cdot 59 \\
0 \cdot 88 \\
0 \cdot 63\end{array}$ & $87 \cdot 3$ & $87 \cdot 0$ & $87 \cdot 3$ \\
\hline
\end{tabular}

${ }^{1}$ Class: So $=$ simple pneumoconiotics-non accident cases.

$\mathrm{S}^{*}$ = simple pneumoconiotics-accident cases.

$\mathbf{P}=$ PMF cases-non-accident.

${ }^{2} \mathrm{R}=\%$ Carbon in dry mineral-matter-free coal.

than the rate for cases of SP. This contrasts with the figures for age at (non-violent) death, which show that, for all the groups, men with SP died at about the same age or younger than men with PMF. There is no significant relationship between accumulation rate and age at death. 


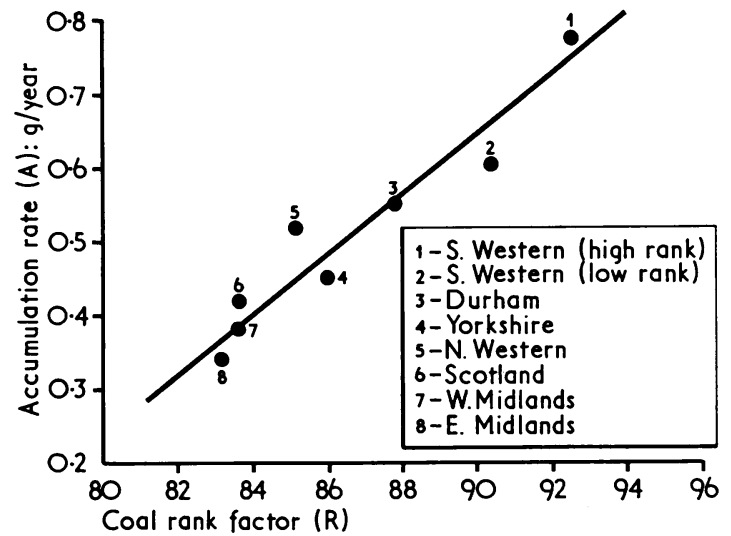

FIG. 1. Relation between accumulation rate of total dust (A) and rank of coal mined (R). Each point represents an average value for a particular coalfield.
In Fig. 1 the average dust accumulation rates are plotted against the average coal rank factors for each coalfield using the data from the 236 cases with SP. From this graph it appears that the two parameters are related, and a regression analysis of these data gave the following results:

Accumulation rate $A=2.70+0.0375$ rank $R$. with a standard error of the rank coefficient of 0.0092 .

However, the equation explains only $6.5 \%$ of the variability of the data. (This corresponds to a statistical correlation coefficient of $0 \cdot 255$.)

Two possible explanations of this tendency are that high-rank coal dust is retained more or eliminated less easily than low-rank coal and associated dust; or that dust conditions in the high-rank areas were worse than in the low-rank areas over the period in which the men worked.

Table 2 shows the percentages of coal $\left(C_{D}\right)$ and

TABLE 2

Average lung Dust Composition in Different CoAlfields

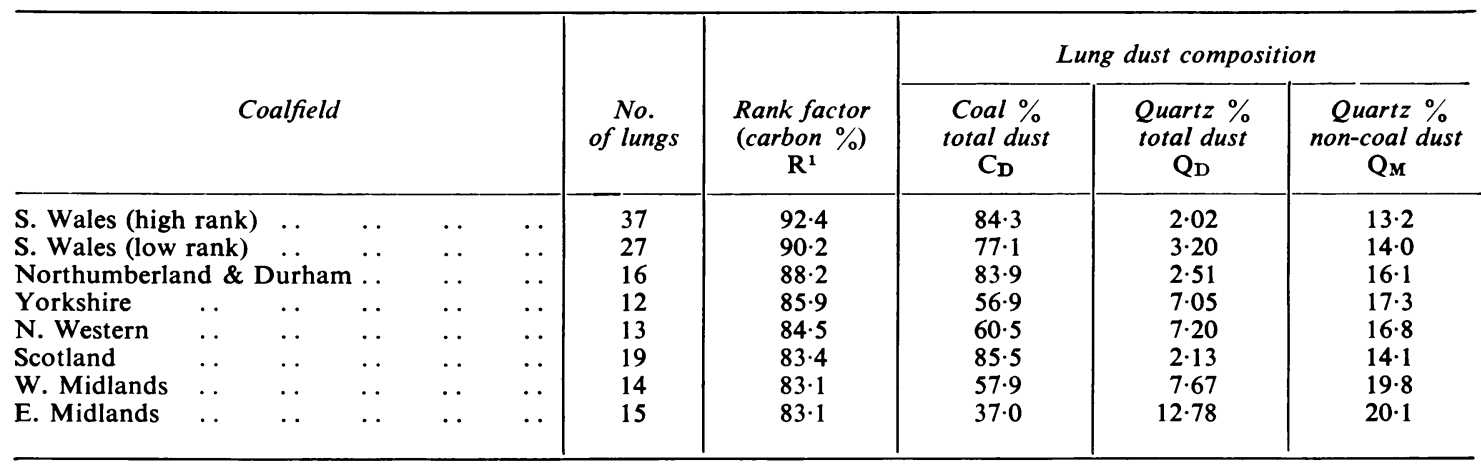

\section{B. Other miners}

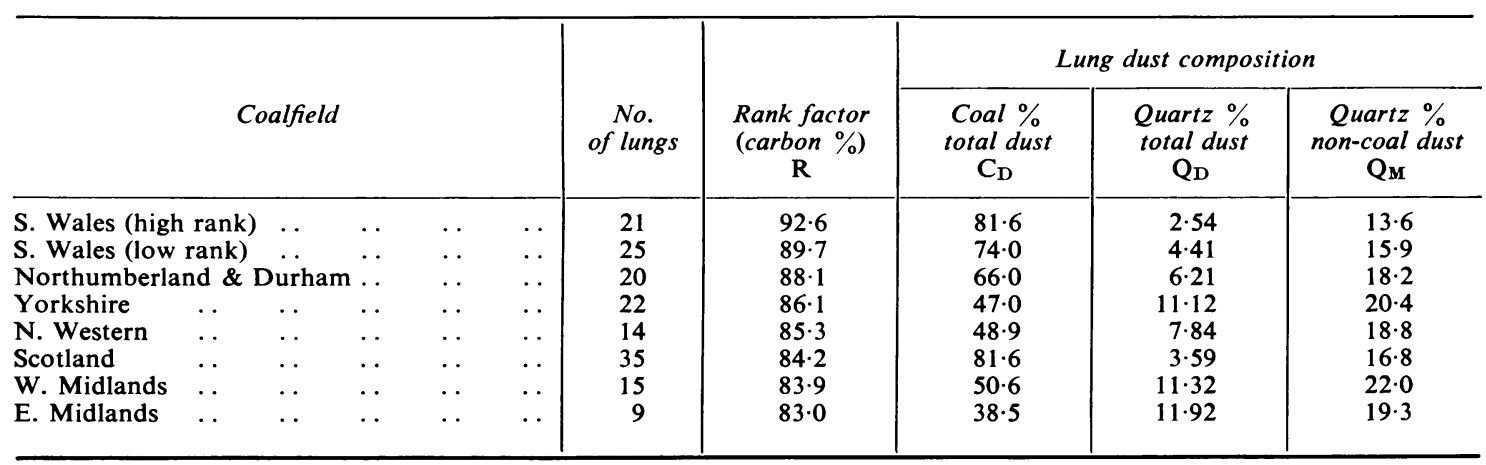

${ }^{1} \mathbf{R}=\%$ Carbon in dry mineral-matter free coal. 
quartz (QD) in the lung dust; and also the percentage of quartz in the mineral (non-coal) fraction of the lung dust $\left(\mathrm{Q}_{\mathbf{M}}\right)$. The values given are averages for each of the eight regional groups; data for coalface workers and for other miners are given separately. The average carbon percentages $R$ indicate the rank of coal mined (high percentages corresponding to high ranks).

In Fig. 2, the average coal percentages of the lung dust $\left(C_{D}\right)$ from the different coalfields are plotted against the coal rank factors $(R)$ at the pits where the men worked. The coal percentage of the lung dust $\left(C_{D}\right)$ for both coalface workers and other miners appears to be consistently related to the rank of the coal mined (R), except for the Scottish groups of lungs.

The coals mined in the Scottish and West Midlands Divisions are characterized by a similar range of rank factor (R). The lung dust parameters shown for these two Divisions in Table 2 are, however, signicantly different. When the individual results for lung-dust coal content $\left(C_{D}\right)$ were graphed against the corresponding rank factors (R) for these Divisions, two disparate populations could be seen; almost all the Scottish miners apparently had a very high proportion of coal $\left(C_{D}\right)$ in the dust in their lungs.

This anomaly has been explained by studies of lung dusts by thermogravimetry (Bergman, 1971) and by microscopy (Bentley and Bergman, 1970). They have shown that in nearly all the Scottish lungs the majority of the combustible material in the residue from the digestion of the lung tissue was soot and not coal. This was due to these coal workers working in 'naked-light' pits where potentially sooty lamps or candles had provided the illumination.

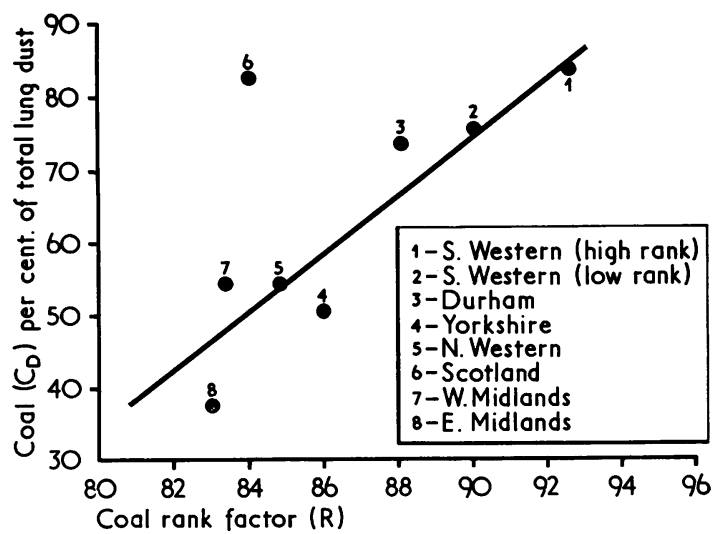

FIG. 2. Relation between coal per cent of total lung dust $\left(C_{D}\right)$ and rank of coal mined $(R)$. Each point represents an average value for a particular coalfield.
However, with the exception of the lungs from Scotland, the lung dust from the different coalfields in Great Britain appears, on average, to contain a higher percentage of coal the higher the rank of coal in the pit. This relation is shown in Figure 3. For each integer value of coal rank factor (R), the coal percent of the total dust $\left(C_{D}\right)$ has been averaged for all those cases with that value of $R$. Those averages are shown as dots in Fig. 3 and the range of values is indicated by the lines through the mean values. For these 260 cases from England and Wales a regression analysis of the data gave the following result:

Coal ( $\%$ total dust) $C_{D}=-290+4.05$ rank $R$ with a standard error of the rank regression coefficient of 0.27 and a correlation coefficient of 0.69 .

When the coalface workers were considered separately, the relationships were not significantly different, although the coalface workers in general have a higher value for the coal content for a given rank value.

The relation between the quartz content of the total lung dust $\left(Q_{D}\right)$ and the rank value $(R)$ is shown in Figure 4. As in Fig. 3, the dots represent

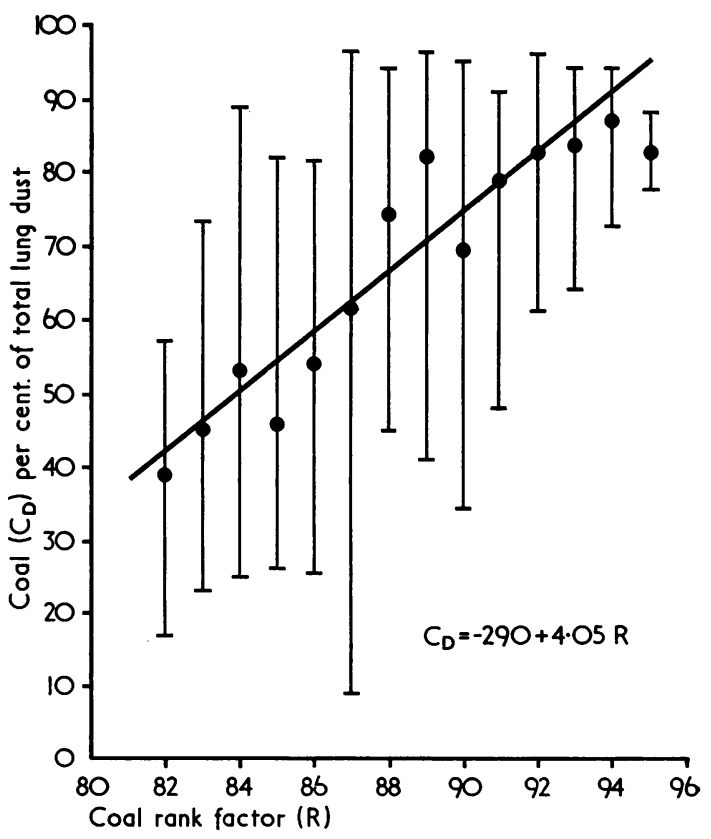

FIG. 3. Relation between coal per cent of total dust $\left(C_{D}\right)$ and rank of coal mined $(R)$. Each point represents an average value of $C_{D}$ for a particular integer value of $R$ independent of the coalfield. Each vertical line indicates the range of values for the associated point. 


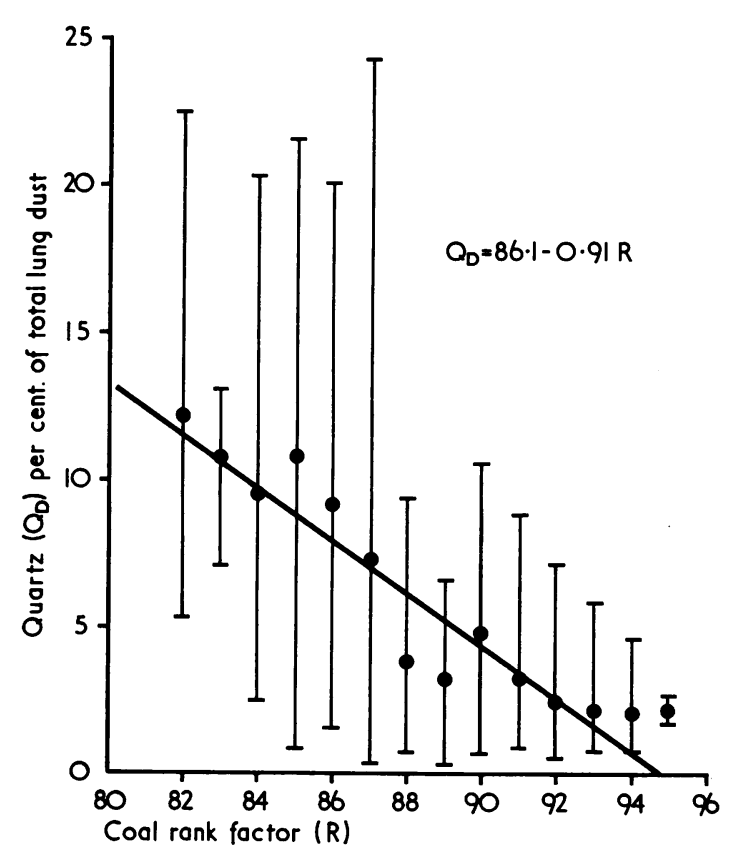

FIG. 4. Relation between quartz per cent of total dust $\left(Q_{D}\right)$ and rank of coal mined (R). Each point represents an average value of $Q_{D}$ for a particular integer value of $\mathbf{R}$ independent of the coalfield. Each vertical line indicates the range of values for the associated point.

mean values of the quartz content ( $\left.Q_{D}\right)$ for those cases with the same integer value of rank $(R)$ and the lines through the mean values represent the range of the values. When the expression relating the dust quartz content $\left(Q_{D}\right)$ and rank ( $R$ ) [also given in Fig. 4 and Table 3] is considered together with that relating the dust coal content $\left(C_{D}\right)$ and $R$, it might suggest that quartz might be a constant proportion of the non-coal or 'mineral' lung dust. In fact this proportion itself varies with rank as is shown in Figure 5. There is a greater proportion of quartz in the non-coal lung dust the lower the rank of coal mined, although the relationship between the quartz content of the non-coal fraction of this lung dust $\left(Q_{M}\right)$ and $R$ [also given in Fig. 5 and Table 3] is not as marked as those for the lung dust coal content $\left(C_{D}\right)$ and the lung dust quartz content $\left(Q_{D}\right)$.

Composition of respirable dust in British coal mines In a recent study (Maguire and Barker, 1971), airborne dust of respirable size was collected with Simgard instruments (Critchlow and Proctor, 1965). The collieries at which samples were taken had been chosen to be representative of the major coalfields of the U.K. and to cover the full range of coal rank. The airborne dust coal content $\left(C_{D}\right)$,

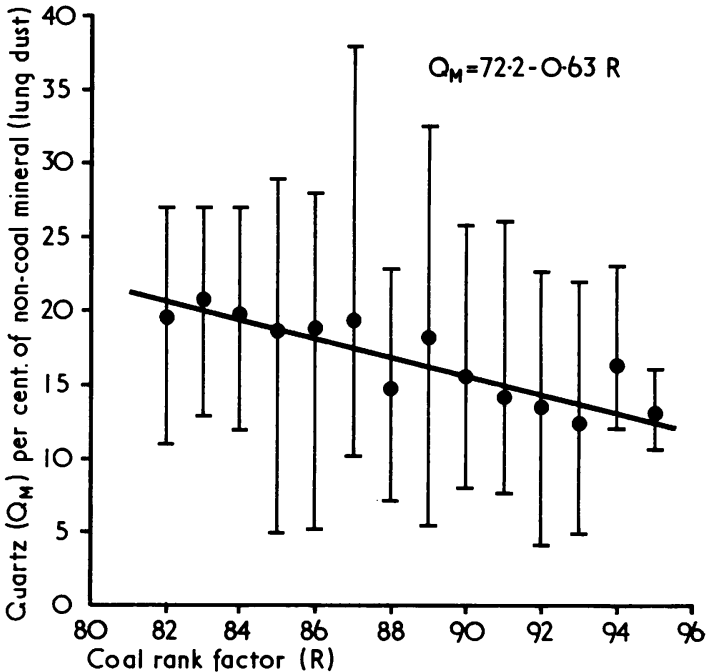

FIG. 5. Relation between quartz per cent of mineral $\left(Q_{M}\right)$ and rank of coal mined $(R)$. Each point represents an average value of $Q_{M}$ for a particular integer value of $R$ independent of the coalfield. Each vertical line indicates the range of values for the associated point.

quartz content (QD), and hence the quartz content of the non-coal mineral $\left(\mathrm{Q}_{\mathrm{M}}\right)$ were determined on these samples and a statistical regression analysis was carried out in the same way as for the lung dusts. The results are given in Table 3.

Results are also included in the table of an analysis of data kindly supplied by the Pneumoconiosis Field Research Scheme of the National Coal Board (NCB). These are data averaged over a decade for 20 pits chosen to be representative of the coalfields of the U.K. The samples were taken with 'thermal precipitators' and the proportions of coal and non-coal were determined by microscopy. Quartz values were deduced from analyses of larger samples.

The statistical regression analyses of the relationships between airborne dust quartz content (QD) and the coal rank factor (R) for both the NCB scheme and for this Simgard study do not yield relationships as good as the corresponding lung dust study. In addition, the regression coefficients for the airborne dust studies are less than half of the regression coefficient for the lung study.

When the airborne dust coal content $\left(C_{D}\right)$ is considered in relation to the coal rank factor (R), the relation for the Simgard study is very poor. This may be because only two samples were taken for each location, and within a period of weeks. The lung analysis data represent averages over working lifetimes; the correlation coefficient of 0.69 indicates a better relationship. The NCB results are averaged 
TABLE 3

Relationship between Coal Rank Factor (R) and ( $a$ ) Dust Coal Content (C $\left.\mathrm{C}_{\mathrm{D}}\right),(b)$ Dust Quartz Content (QD), AND (c) Non-COAL-Mineral Quartz ConTent (Q M)

\begin{tabular}{|c|c|c|c|c|c|c|}
\hline Dependent variable & Dusts from & $\begin{array}{l}\text { No. of } \\
\text { cases }\end{array}$ & $\begin{array}{l}\text { Regression } \\
\text { coefficient } \\
\text { of } R\end{array}$ & $\begin{array}{l}\text { Standard } \\
\text { error }\end{array}$ & Constant & $\begin{array}{l}\text { Correlation } \\
\text { coefficient }\end{array}$ \\
\hline $\begin{array}{l}\text { (a) } \\
\text { Dust coal content }\left(\mathbf{C}_{\mathbf{D}}\right) \quad \ldots\end{array}$ & $\begin{array}{l}\text { Lungs } \\
\text { Simgard } \\
\text { trials } \\
\text { NCB survey }{ }^{1}\end{array}$ & $\begin{array}{r}260 \\
112 \\
\times 2 \\
20\end{array}$ & $\begin{array}{l}4 \cdot 05 \\
2 \cdot 18 \\
\\
2 \cdot 61\end{array}$ & $\begin{array}{l}0.27 \\
0.41 \\
\\
0.43\end{array}$ & $\begin{array}{l}-290 \\
-125 \\
-164\end{array}$ & $\begin{array}{l}0.69 \\
0.45 \\
\\
0.82\end{array}$ \\
\hline $\begin{array}{l}\text { (b) } \\
\text { Dust quartz content }\left(Q_{D}\right)\end{array}$ & $\begin{array}{l}\text { Lungs } \\
\text { Simgard } \\
\text { trials } \\
\text { NCB survey }\end{array}$ & $\begin{array}{r}260 \\
112 \\
\times 2 \\
20\end{array}$ & $\begin{array}{l}-0.91 \\
-0.29 \\
-0.26\end{array}$ & $\begin{array}{l}0.07 \\
0.06 \\
\\
0 \cdot 11\end{array}$ & $\begin{array}{l}86 \cdot 1 \\
28 \cdot 8 \\
\\
27 \cdot 2\end{array}$ & $\begin{array}{l}0.66 \\
0.36 \\
0.50\end{array}$ \\
\hline $\begin{array}{l}(c) \\
\text { Non-coal-mineral quartz content }\left(\mathrm{Q}_{M}\right) . .\end{array}$ & $\begin{array}{l}\text { Lungs } \\
\text { Simgard } \\
\text { trials } \\
\text { NCB survey }\end{array}$ & $\begin{array}{r}260 \\
112 \\
\times 2 \\
20\end{array}$ & $\begin{array}{l}-0.63 \\
-0.40 \\
-0.40\end{array}$ & $\begin{array}{l}0.09 \\
0 \cdot 10 \\
0 \cdot 23\end{array}$ & $\begin{array}{l}72 \cdot 2 \\
44 \cdot 2 \\
\\
14 \cdot 4\end{array}$ & $\begin{array}{l}0.39 \\
0.41 \\
0.04\end{array}$ \\
\hline
\end{tabular}

${ }^{1}$ National Coal Board Pneumoconiosis Field Research Survey.

out over a period of 10 years; the correlation coefficient is the best at 0.82 .

The mean value for the coal rank factor $(R)$ is somewhat higher for the lung dust than for the airborne dust studies. This is because the Scottish lungs [corresponding to a low R] had to be excluded from the study, because of the preponderance of lungs available from South Wales, and because the coal mined in the U.K. has, on average, become of lower rank of late.

This might be a factor in the lower regression coefficients for the dust coal content $\left(C_{D}\right)$ (airborne) and $R$ compared to that between $C_{D}$ (lung) and $R$. The relationships do not differ markedly in the region of average rank factor (R). They do, however, diverge for the extremes of rank, although within the limits of $R=82$ to $95 \%$ differences in $C_{D}$ between the relationships are not significant. This might suggest that the modern methods of mining (e.g., almost entirely 'machine-getting' of coal) produce dust, the ash content of which is less dependent on the rank of the coal mined than when the coal was 'hand-got'. An alternative explanation is that the modern methods of mining vary less with the rank of the coal than they did over the first half of the century when the miners in the present study were at work.

The correlation between rank and coal percentage in the respirable dust was just as good for the Scottish respirable dust samples as for those from the other divisions. However, these dust samples were relatively recent, whereas Scottish miners whose lungs have been analysed on the average stopped work underground in 1949.
Iron content of coal-workers' lungs

Abnormally high amounts of iron-containing material are found in pneumoconiotic lungs; the quantity of this material (expressed in terms of the iron) is related to the coal and mineral contents of the lungs (Rossiter et al., 1967; Casswell, Bergman, and Rossiter, 1971) and is probably due to the deposition of an endogenous material such as haemosiderin (Bergman, 1970). It is conceivable that the formation of iron deposits in the lung might continue both during and after exposure to atmospheric dust. The factors 'years in' (i.e., years underground) and 'years out' (i.e., years since retirement from the pit) were therefore included with lung coal $\left(C_{L}\right)$, lung mineral $\left(M_{L}\right)$, and lung quartz $\left(Q_{L}\right)$ contents in a statistical study of their relationship with lung iron content as the dependent variable.

The correlation of mineral with quartz was so high that they could not properly be included in the statistical analysis together. The replacement of mineral by quartz in the analysis added nothing to the relationship, so the latter factor was not considered further in relation to the lung iron content.

The group of cases with SP was considered as a whole and also subdivided in a number of ways. The first division was into two groups according to the cause of death-'pit accident' and natural death. The second division was into three groups according to the coal region in which the men had worked-Scotland, Wales or England. The group from England was further subdivided into coalface workers and other underground workers.

For none of these categories was there any significant correlation of lung iron content with the 
factor 'years out'. This may be because the formation of lung iron deposits does not continue after dust exposure ceases, or merely because the time involved was, on average, too short.

Table 4 shows the statistical parameters obtained for the entire SP group and for those subgroups for which the multiple correlation coefficient, and hence the proportion of the variability explained, was increased by the division.

When the pit accident cases were considered separately, the factor 'years in' and mineral (ML) both increased in significance, as shown by the simple correlation coefficients, and the latter doubled in its contribution to the regression. The effect on the time relationship was surprising, because the number of years underground was smaller for the pit accident group. The group was made up of about an equal number of cases from England and Wales. This makes the high correlation level surprising, because none of the relationships was particularly good for the group from Wales. It may be that the biological mechanism whereby mineral in the lung produces iron deposits with time in younger people is less effective as age increases.

When the SP cases from England were considered separately from those from Wales and Scotland, the factors coal $\left(C_{L}\right)$ and mineral $\left(M_{L}\right)$ increased in significance, as shown by the simple correlation coefficients, and the latter doubled in its contribution to the regression. The factor 'years in' was no longer significant. This is in contrast to the Scottish group for which the subdivision increased the significance of 'years in', as judged by the simple correlation coefficient, and doubled its contribution to the regression, while mineral $\left(\mathrm{M}_{\mathrm{L}}\right)$ lost its significance. The lung dusts from Scotland consist largely of fine soot particles (Bentley and Bergman, 1970). It may be that the large surface area associated with such a material results in the production of iron deposits continuing over a period of time.

Where, as for the cases from England and Wales, the time factor is not significant, it could be either that the coal and mineral form iron deposits in the lung extremely slowly, or that the deposits are formed quickly but do not progress with time.

Almost the only effect of subdividing the SP cases from England further, and considering the group of coalface workers separately, was to improve the relationship (correlation coefficient increased from 0.65 to 0.75 ). This reflects the more homogeneous exposure of this group to atmospheric dust.

Iron has an absorption coefficient for the $x$ rays used in diagnostic radiography much higher than those of coal or other minerals recovered from the lungs of British coal miners. It is not surprising, therefore, that when various parameters are individually examined statistically in relation to the radiological category of pneumoconiosis, the iron content of the lung tissue contributes more to the relationship than do the lung coal or lung mineral contents (Rossiter et al., 1967; Casswell et al., 1971). Indeed it is likely that materials like coal mine dust give rise to the radiological appearance of simple pneumoconiosis mainly through their stimulation of iron deposits in the lungs. The results of the present work are, therefore, of interest, in that the ability of dusts to lead to iron deposits depends on the factors studied in such a complex manner, and would clearly repay further study.

Airborne dust levels in British mines could not be measured systematically until the last two decades. Where there were differences in the incidence of pneumoconiosis between different coalfields, the reasons could only be guessed. It is likely that these differences result from the combination of a number of factors. The relationships demonstrated in the

TABLE 4

Results of Statistical Analysis for Simple Pneumoconiosis Group and a Number of Subdivisions, of Relationship between Lung Iron Content as Dependent Variable and Years in, Lung Coal Content $\left(C_{D}\right)$ AND Lung Mineral CONTENT (MD)

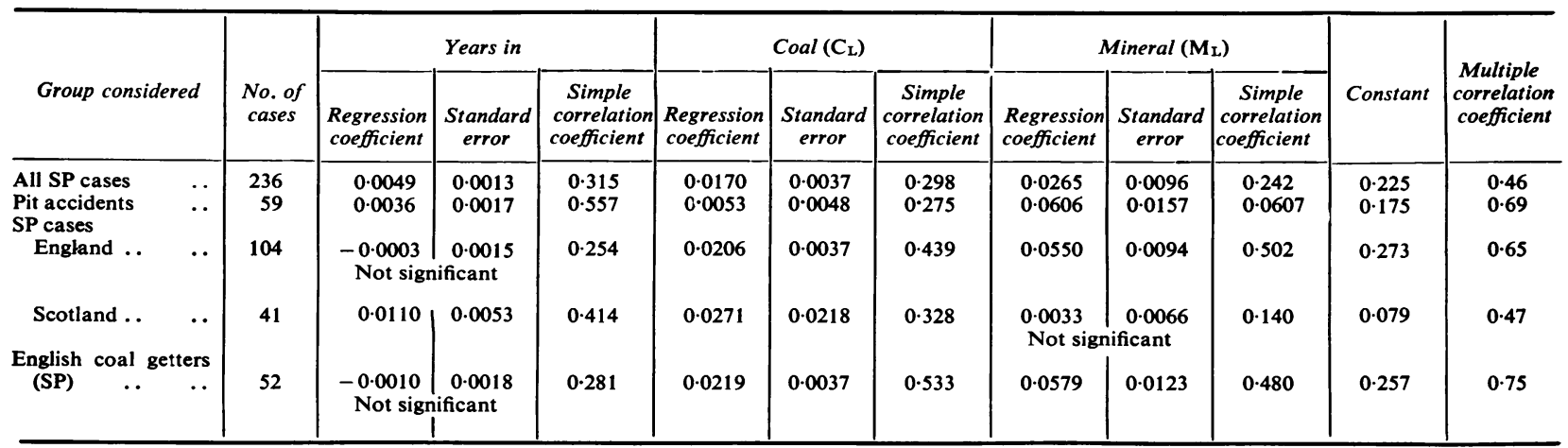


present work are likely to be such contributory factors.

\section{References}

Bentley, R. A., and Bergman I. (1970). Candle or oil soot as a cause of pneumoconiosis in coal miners. Ann. occup. Hyg., 13, 109-113.

Bergman, I. (1966). Determination of coal in formalin-fixed pneumoconiotic lungs: new method of tissue digestion using glacial acetic acid. Analyt. Chem. (Wash.), 38, 441-444.

(1970). The relation of endogenous non-haem iron in formalin-fixed lungs to radiological grade of pneumoconiosis. Ann. occup. Hyg., 13, 163-169.

(1971). A new method for evaluating the rank of coal from thermogravimetric curves: the identification of combustible materials isolated from pneumoconiotic lungs. Fuel. (In press.)

Casswell, C., Bergman, I., and Rossiter, C. (1971). The relation of radiological appearance in simple pneumoconiosis to the composition and dust-content of the lungs of coal workers. Inhaled Particles and Vapours, III, Proc. 3rd Int. Symp. London, 1970, edited by W. H. Walton, pp. 713-726. Unwin, London.

Critchlow, A., and Proctor, T. C (1965) Simgard: a new portable instrument for gravimetric estimation of respirable airborne dust. Colliery Guardian, 211, 208-209.

Cullen, T. J. (1962). Coherent scattered radiation internal standardization in X-ray spectrometric analysis of solutions Analyt. Chem., 34, 812-814.

Faulds, J. S., King, E. J., and Nagelschmidt, G. (1959). The dust content of the lungs of coal workers from Cumberland. Brit. J. industr. Med., 16, 43-50.

Gordon, R. L., and Harris, G. W. (1956). Geiger-Müller counter equipment for quantitative $\mathrm{X}$-ray diffraction analysis of powders. Safety in Mines Research Establishment Research Report No. 138.

King, E. J., and Gilchrist, M. (1945). Chronic pulmonary disease in South Wales coal miners. III.-Experimental studies. Spec. Rep. Ser. med. Res. Coun. (Lond.), No. 250, pp. 21-28.

, Maguire, B. A., and Nagelschmidt, G. (1956). Further studies of the dust in lungs of coal-miners. Brit. J. industr. Med., 13, 9-23.

Maguire, B. A., and Barker, D. (1971). Ash and quartz content of respirable airborne dust in a number of British coal mines. Safety in Mines Research Establishment Research Report No. 278.

Nagelschmidt, G. (1960). The relation between lung dust and lung pathology in pneumoconiosis. Brit.J. industr. Med., 17, 247-259.

National Coal Board (1960). The Coalfields of Great Britain, Variation in Rank of Coal. N.C.B., London.

Rivers, D., Wise, M. E., King, E. J., and Nagelschmidt, G. (1960). Dust content, radiology, and pathology in simple pneumoconiosis of coalworkers. Part I, General observations; Part II, Detailed analysis. Brit. J. industr. Med., 17, 87-108.

Rossiter, C. E., Rivers, D., Bergman, I., Casswell, C., and Nagelschmidt, G. (1967). Dust content, radiology and pathology in simple pneumoconiosis of coalworkers. In Inhaled Particles and Vapours II; Proc. 2nd Int. Symp. Cambridge, 1965, edited by C. N. Davies, pp. 419-437. Pergamon, Oxford.

Spink, R., and Nagelschmidt, G. (1963). Dust and fibrosis in the lungs of coal-workers from the Wigan area of Lancashire. Brit. J. industr. Med., 20, 118-123.

Wootton, I. D. P. (1958). Determination of iron in biological material by spectrophotometry of ferric perchlorate. Biochem. J., 68, 197-199.

Received for publication July 2, 1971. 